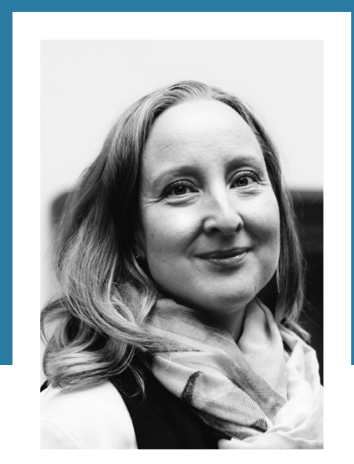

\title{
P̈̈̈̈KIRJOITUS
}

\section{AIKUISKASVATUKSELLA ON MONIA MAHDOLLISIA TULEVAISUUKSIA}

E

PÄVARMUUS TUleVASTA on ollut esillä kuluneen kevään aikana. Pandemia nosti esiin kysymyksen siitä, miten paljon voimme vaikuttaa omaan tulevaisuuteemme, saati koko maailman kehitykseen.

Myös aikuiskasvatuksen tulevaisuuksien pohdintaan tarvitaan suuntaviivoja. Niitä tarjoavat useat asiantuntijatahot, esimerkiksi valtioneuvosto selonteoillaan ilmastopolitiikasta, hyvinvoinnista ja työn murroksesta. Samoin toimivat opetus- ja kulttuuriministeriön ja Opetushallituksen koordinoima "Osaamisen ennakointifoorumi" kartoituksillaan tulevista osaamis- ja koulutustarpeista sekä talousjärjestö OECD kuvauksillaan tulevaisuuden megatrendeistä.

AIKUISKASVATUKSEN JA ELINIKÄISEN OPPIMISEN merkitys korostuu sekä kansallisissa että monikansallisissa tulevaisuusskenaarioissa. Aikuiskoulutusta tarvitaan pitämään yllä demokraattista ja tasa-arvoista yhteiskuntaa mutta myös tuottamaan valmiuksia tulevaisuuden työtä varten. Sitä tarvitaan silloinkin, kun työtä ei riitä kaikille. Ennakoidaan, että työelämä eriytyy, ja työtä tehdään yhä monimuotoisemmilla ja monimutkaisemmilla tavoilla.

Työn murrokseen kuuluvat monialaisuus ja -ammatillisuus - selkeiden ammattiroolien ja työtehtävien rajojen hämärtyminen ja uudenlaiset yhteistyökäytännöt. Niitä tarkastellaan tämän numeron tiedeartikkeleissa.

Mahdollisia tulevaisuuksia on tärkeä pohtia juuri nyt, kun pandemian myötä talous, työ ja yhteiskunta ovat muutoksessa. Tulevaisuudentutkimus on monitieteinen tiedonala, jonka tehtävä ei ole ennustaa vaan luoda tutkimustiedon perusteella kuvauksia todennäköisistä ja vaihtoehtoisista tulevaisuuksista. Tulevaisuus on tulevaisuudentutkimukselle ilmiö, joka ei synny tyhjästä vaan pikemminkin pitkän linjan jatkumoissa. Niiden etenemisvauhtia ja suuntaa pandemian kaltaiset yllättävät kriisit voivat muuttaa.

TUTKIMUKSEN KRIITTINEN TEHTÄVÄ on tunnistaa, millaiset tahot pyrkivät ohjailemaan tulevaisuuden suuntaa ja millaisia pyrkimyksiä niillä on. Kysymystä eri toimijoiden korkeakoulutuksen tulevaisuuksiin kohdistuvista pyrkimyksistä ja ideoista pohdittiin dosentti Johanna Kallon kanssa toteuttamassamme paneelissa Nordic Educational Research Association (NERA) 2020 -konferenssissa. Keskusteluun osallistuivat korkeakoulutuksen historiaa ja yhteiskunnallista tehtävää tutkinut professori Jussi Välimaa, korkeakoulutuksen muutosta ja reformeja tutkinut valtio-opin emeritusprofessori Ivar Bleiklie ja globalisaatiota, kansainvälistymistä ja koulutuspolitiikkaa tutkinut professori Fazal Rizvi ${ }^{1}$.

Aikuiskasvatuksen on tärkeä jatkaa paneelissa virinnyttä keskustelua koulutuksen tulevaisuuspolitiikasta. Millä tavoin ylikansalliset organisaatiot tai 
LEHTEMME ON VASTAKIN FOORUMI,

JOSTA AMMENTAA TIETOA, IDEOITA JA SUUNTAA

AIKUISKASVATUKSEN TULEVAISUUKSILLE.

yritysten ja julkisten toimijoiden muodostamat verkostot yrittävät vaikuttaa aikuiskasvatuksen tulevaisuuteen? Minkälaista koulutusta, kenelle, keiden järjestämänä ja millä hinnalla ne pyrkivät edistämään? Tulevaisuudesta käydään kamppailua. Eri toimijat näkevät erilaisia tulevaisuuksia mahdollisina (Kallo ym. 2018). Siksi ei ole samantekevää, ketkä pääsevät koulutusvisiointiin mukaan ja millä ehdoin.

TULEVAISUUDEN MUUTOKSET tulee suhteuttaa ilmiöiden laajempiin historiallisiin kehyksiin. Kun tunnemme menneisyyttä, ymmärrämme, kuinka aiemmat oivallukset, valinnat ja päätökset vaikuttavat tähän päivään ja tulevaisuuteen. Ensinnäkin omilla valinnoilla vaikutamme omaan tulevaisuuteemme, ja jos miljoonat ihmiset ottavat askelia samaan suuntaan, valinnoillamme on merkitystä maailman mittakaavassa. Toiseksi historiasta seuraa se, että kaikki ei ole mahdollista ${ }^{2}$.

Voimme vahvistaa aikuiskasvatustieteen tulevaisuusorientaatiota perehtymällä tulevaisuudentutkimuksen menetelmiin ja soveltamalla niitä oman alamme tutkimukseen. Yhtä tärkeää on tuntea oma historiamme. Historiantaju auttaa kyseenalaistamaan yksiulotteiset ja vaihtoehdottomat tulevaisuuskuvat.

Tulevina viikkoina Aikuiskasvatus on luettavissa vapaasti verkossa koko julkaisuajaltaan, vuodesta 1981 lähtien. Julkaisuarkistoa selailemalla voimme hahmottaa aikuiskasvatuksen tutkimuksen pitkiä linjoja ja havaita, kuinka käsitykset ilmiöistä ovat muuttuneet ajan saatossa ja uudistaneet tutkimusta. Paljon arvokasta on myös säilynyt samana.
Aikuiskasvatus täyttää ensi vuonna 40 vuotta. Juhlavuosi on hyvä aika iloita pitkästä olemassaolosta - ja katsoa tulevaisuuteen tuorein silmin. Lehtemme on vastaisuudessakin foorumi, josta ammentaa tietoa, ideoita ja suuntaa aikuiskasvatuksen tulevaisuuksille.

\section{Ulpukka Isopahkala-Bouret}

Pääkirjoitusta on korjattu 16.6.2020 lisäämällä viittaukset kirjoituksen taustalla olevaan yhteistyöhön, aiempaan tutkimukseen aiheesta ja polkuriippuvuuden käsitteeseen.

1Paneelikeskustelun lisäksi työstimme dosentti Johanna Kallon johdolla, yhdessä professori Jussi Välimaan kanssa ehdotuksen erikoisnumerosta Whose Future? Analyzing the Visions and Scenarios of Nordic Higher Education. Tarkastelen pääkirjoituksessa yhteistyöhömme pohjaavia ideoita aikuiskasvatuksen näkökulmasta.

${ }^{2}$ Tämä ajatus perustuu vertailevassa koulutuspolitiikan tutkimuksessa yleisesti käytettyyn 'polkuriippuvuuteen'. Termillä viitataan muun muassa pitkään tiettyä polkua edenneiden tapahtumakulkujen palautumattomuuteen.

\section{Lisää aiheesta:}

"Actors and ideas shaping the futures of higher education in the Nordic countries". Paneelikeskustelu NERA 2020 -konferenssissa Turussa 6.3.2020. https:// nera2020.fi/panel-discussion.

Kallo, J., Takala, T., Gorodski Centeno, V., \& Suominen, O. (2018). Alternative views of the future of quality assurance and evaluation. Teoksessa J. Kauko, R. Rinne \& T. Takala (toim.) Politics of Quality in Education. A Comparative Study of Brazil, China and Russia. New York: Routledge, 161-179.

Kouvo, T. (2020). Digitointi avaa tiedelehden laajalle lukijakunnalle. Tietolinja, 2020(1). http://urn.fi/ URN:NBN:fi-fe2020050324722. 